\title{
Manuscript Readings in Homeric Hymn to Demeter 389-479
}

In December $2011 \mathrm{I}$ had the pleasure of studying Leidensis BPG 33H, a manuscript which once, after its discovery by C.F. von Matthaei in Moscow in 1777, gained celebrity throughout the discipline as the sole manuscript to contain the Homeric Hymn to Demeter (siglum M). ${ }^{1)}$ I paid special attention to f. 35, the loss of around a third of which has damaged our text of H.Dem. 387$404,437,462-79$. Subsequently a reader of the manuscript found this damaged page, cut out a new piece of paper to fit the gap, pasted it over the fraying edges of the original recto, then inked in some text on both recto and verso, not only on his added paper but also over some of the letters in the first hand (Ioannes Eugenikos); this writer's work is distinguished by the siglum $\mathrm{m}^{2}{ }^{2}$ Where $\mathrm{m}$ offers just a few letters, he presumably copied what he could read (or thought he could read) on the original under the glued area, so that the readings have some claim to authority. Elsewhere, $\mathrm{m}$ conjectures formulas to fill out a half-line, or uses parallel passages to fill out nearly the whole verse. ${ }^{3)}$ Ruhnken's editio princeps of the Hymn to Demeter (1782) gives a sense of what Matthaei (who transcribed M for Ruhnken) saw on the page after m's intervention; similarly, with autopsy and slightly more detail, Mitscherlich 1787 and Schneidewin's reports in Baumeister 1860. The glued-on sheet was removed at the direction of Willem Pluygers around 1860. ${ }^{4}$ It is now preserved separately inside the volume. This process exposed some original letters which had been glued over, and a few which had imprinted themselves on the verso of the added sheet. However, the glue has darkened several letters on each line, and it requires minute attention to decipher these extra letters.

Such attention was given particularly by Buecheler and, most of all, by Goodwin and Allen in Goodwin 1893. Goodwin also provides photographs of the current state of the page and the added sheet. Some of the detail of these older commentaries disappeared in Richardson's more succinct apparatus. Despite Goodwin's impressive efforts, my readings diverged from his at various points, which are the subject of this article.

389: This is my most significant correction. Goodwin and subsequent editors report $\theta$ ćc1[ M: $\theta$ cív m. I read $\theta$ cọ́ M: $\theta$ ćcıv m. ${ }^{5}$ Buecheler describes aptly how after M's theta he saw 'ductus adsimilis $\delta$ litterae', but he did not recognise this as a ligature of $\varepsilon 0$, where $\varepsilon$ is written above the line like a hook. This ligature recurs frequently in $\mathrm{M}$, for example in $404 \theta \varepsilon o \hat{c}{ }^{6}{ }^{6}$

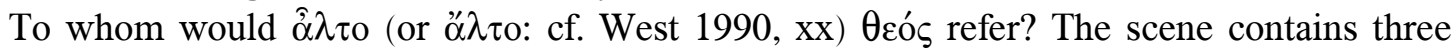
deities - Persephone, Demeter, and Hermes. Although the subject was Hermes in 384, it has since

\footnotetext{
1) For this opportunity I am grateful to Richard Hunter, André Bouwman, and the helpful library staff in Leiden. I also thank Nicholas Richardson, Andrew Faulkner and Mnemosyne's referee for their comments. I cite the following editions by the editor's surname alone: Buecheler 1869, Goodwin 1893, Richardson 1974. In such cases, understand 'ad loc.' unless otherwise stated. For M's history see Gelzer 1994.

2) M's scribe was identified by Harlfinger $(1977,335, \mathrm{n} .33)$. $\mathrm{m}$ is normally dated to the sixteenth century, though Allen ap. Goodwin 1893, ix-x places him later.

${ }^{3)}$ These supplements demonstrably do not derive from damaged parts of the original page which are no longer extant. m's supplements in lines 1-10 of recto and verso do not correlate with each other in length, and his

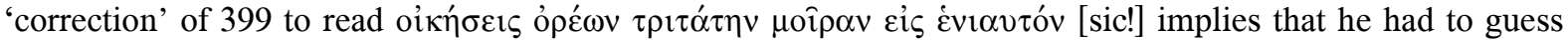
further down the column too.

4) Pluygers became librarian in 1859; the detachment is referred to as complete at Hignard 1864, 31 .

5) Where possible, I have updated earlier transcriptions to make use of dotted letters. As in a diplomatic transcript, $\alpha$ here indicates 'traces probably representing alpha' and indicates 'an ambiguous trace'.

${ }^{6}$ ) In M's numbering (and hence on facsimiles), this is labelled line 403. Buecheler provides a complete facsimile of $\mathrm{M}$ for the Hymn to Demeter, sadly not digitised satisfactorily by Google Books (http://books.google.co.uk/books?id=q1UVAAAAQAAJ, accessed 11 August 2013). Merkelbach and van Thiel $(1965,1-5)$ give a facsimile of M for H.Hom. 1 and H.Dem. 1-232; the Eo ligature is visible there at e.g.

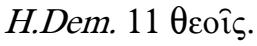


changed twice and I cannot convincingly reconstruct a way to switch back to him which includes $\theta \varepsilon$ ó . If, however, $\theta \varepsilon$ có is feminine, the subject of $\alpha$ ' $\lambda \tau$ o is likely to be Persephone, since we have already been told that Demeter $\ddot{\eta} i \xi_{\varepsilon}$ at 386 . Epic uses of $\theta \varepsilon$ có $\varsigma$ as a feminine fall into three broad categories ( $\operatorname{fgr} E$ s.v. 4): (i) where $\theta \varepsilon \alpha$ is not metrically possible; (ii) where there is a deity vs human antithesis; (iii) where the gender is clarified by a preceding feminine adjective. None of these cases apply here, but I suspect $\theta$ có $\varsigma$ might have been followed by an adjective. Among many alternatives, $\sigma \varepsilon \mu v \eta \dot{~(H . D e m . ~ 1) ~ o r ~ \kappa v \delta \rho \eta ́ ~(H . D e m . ~ 179) ~ w o u l d ~ f o r g e ~ a n ~ a p p r o p r i a t e ~ l i n k ~ b e t w e e n ~}$ mother and daughter. The formula \{foot-and-a-half-long subject $+\dot{\varepsilon} \tau \varepsilon \dot{\varepsilon} \rho \theta \varepsilon v\}$ (387), which occurs another 29 times in early epic, is generally followed directly by a main verb or a prepositional phrase, and only at II. 16.427 by a temporal clause as in the supplements of Voss and Goodwin. With so many possibilities it would be misleading to suggest any particular reconstruction in Greek, but the approximate shape of the passage may have been: 'On the other side Persephone, [weeping, wailed upon beholding] her mother's [dear face, and then] the [venerable] goddess leapt up...' or 'On the other side Persephone, [on her chariot, upon beholding] her mother's [dear face], leapt up, the [venerable] goddess,...'.

I cannot explain why $\mathrm{m}$ failed to reproduce M's $\varepsilon$ o ligature. His traces begin with the bottom of a $\theta$, followed by a high loop. If this is a single $\theta$, as recent editors suggest, the shape is abnormal, as is the $\theta-\varepsilon$ join. But Schneidewin reported (in Baumeister 1860) that m's sheet left part of M's theta visible. m's traces therefore represent only the completion of the lower part of theta, followed by a ligatured epsilon ballooning above the line, as often in M. This naturally displaced the acute accent to the right, above iota. $m$ therefore intended $\theta$ '́ctv.

390: $\mathrm{m}$ has $\hat{\eta} \delta \varepsilon$ (so Buecheler) not $\ddot{\eta} \delta \varepsilon$.

391: the position of M's lenis is compatible with either $\alpha$ or $\alpha$ '.

392: Thompson ap. Goodwin suggested $\pi \alpha<v>0 \mu$. [ for M's traces. I think a case of

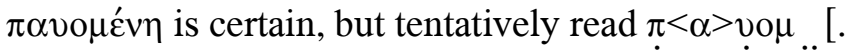

393-4: M writes iota subscripts very rarely, so they are not to be taken lightly. One appears

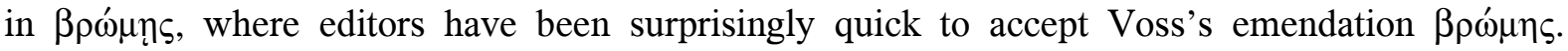

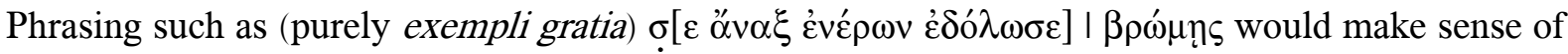
the dative, give the speech ring-composition to underline Demeter's anxiety (cf. 404), and suggest

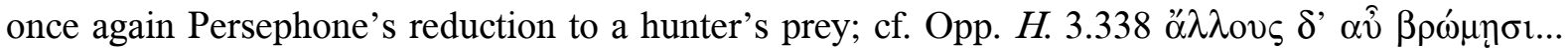
$\delta o \lambda \omega ́ \sigma \alpha \varsigma$, of a fisherman.

394: $\mu$, as suggested by the parallel to II. 16.19, is certain: the traces noted by Buecheler point unmistakably to a mu, while Goodwin $(1893,18)$ found a transfer of the $\grave{\eta}$ in the right place on the verso of the glued-on sheet.

399: read $\mu \varepsilon^{\prime} \rho 0\left[\right.$ not $\mu \varepsilon \varepsilon_{\rho}[$.

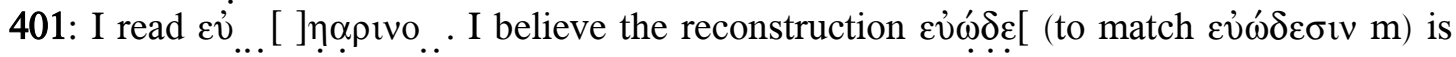
incompatible with M’s traces. The first ambiguous trace, after upsilon, most resembles a tall epsilon, or the left-hand half of theta, except with a short vertical line through the top. I also suspect that word was nominative: with $\varepsilon \dot{v} \omega \dot{\delta} \varepsilon \sigma \mathrm{v} v$ 'sanequam offendunt tria epitheta florum iuxta posita'

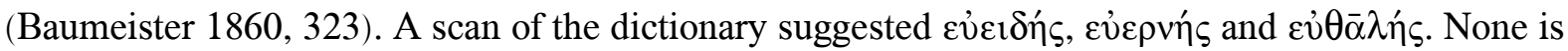

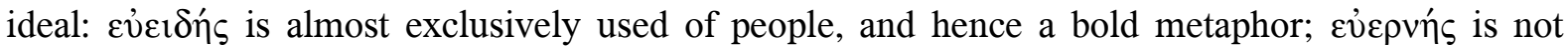
especially apt for talk of flowers; $\varepsilon \dot{v} \theta \bar{\alpha} \lambda \eta ́$ s is extremely rare (e.g. Philip 44.1 GP2925, H.Ares 9).

405: $M$ has öv lov (note accent).

406-7: Between the ends of these lines, in the inter-columnar margin, is a horizontal written by neither Eugenikos nor m. As Buecheler saw but Goodwin neglected, this cues a comment in the bottom margin, of which only the corresponding horizontal marker survives.

474: I was unable to verify any of the initial traces $\delta^{-\rho}$ from which both Buecheler and Goodwin inferred the verb $\delta \varepsilon \hat{\imath} \xi \varepsilon$. 


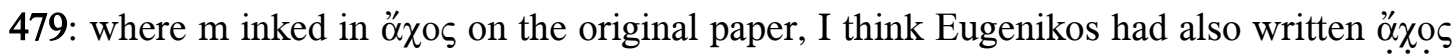
beneath; Buecheler also believed the first letter was $\alpha$. Goodwin, however, was adamant that it is $\sigma$,

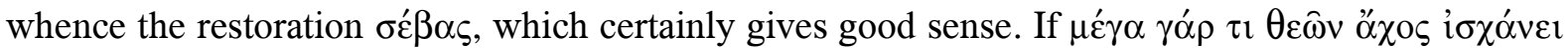
$\alpha$ ' $\delta$ ' $v$ was M's reading, the sense would be that the goddesses' past grief (as commemorated at the Mysteries) creates a situation in which one must restrain one's tongue; Metaneira failed to do so at 242-9, and exacerbated Demeter's rage. However (as Richardson has pointed out to me), to retain ö $\chi 0 \varsigma$ one should emend $\tau$, since a specific ö $\chi 0 \varsigma$ which we have been told about is being referred to.

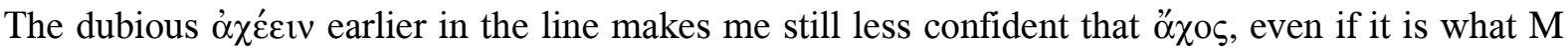
wrote, is reliable.

A final point which deserves elaboration is how best to understand and evaluate m's behaviour. The greatest insight comes from his treatment of the lines now numbered 462-5. Eugenikos, distracted by the similarity of 461-5 (Rhea relating Zeus' instructions) to 443-7 (Zeus instructing Rhea), had let his eye skip back to the earlier passage, which was just inches away in the left-hand column of his page, and probably of his exemplar's page. Eugenikos blithely continued writing out 448-51, then realised his error, left a blank, and restarted from 466. After the page was damaged, M's column thus presented $m$ with line-ends to match 444-451, then a blank line-end, then the latter half of 466. m's first response to this situation was to fill in the blank with the second half of 452: he recognised the line-ends as matching the earlier passage, and keenly continued the pattern. It may even have been this which prompted him to glue in his sheet, because he felt able to fill in several words at a time. ${ }^{7)}$ He hastily restored 462-4, working from his memory of 444-6 rather than checking carefully: hence he wrote $\ddot{\alpha} \varsigma \kappa \varepsilon \theta \dot{\varepsilon} \lambda \eta \sigma \theta \alpha$ [sic] where Ilgen's $\ddot{\alpha} \varsigma \kappa \varepsilon \nu$ ह̌ $\lambda$ oro provides the proper match. Then m stopped, realising too late why Eugenikos had left that blank space: the upcoming 448-9 produce nonsense if repeated here. $m$ then had to decide which of M's lines

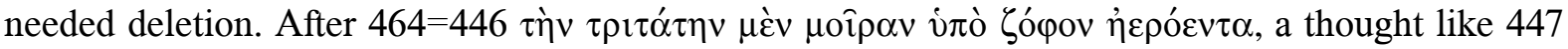
$\tau \grave{\alpha} \varsigma \delta \grave{\varepsilon} \delta \dot{v} \omega \pi \alpha \rho \grave{\alpha} \mu \eta \tau \rho i ́ . .$. was needed. m thought he could fit it into the start of 466, with his

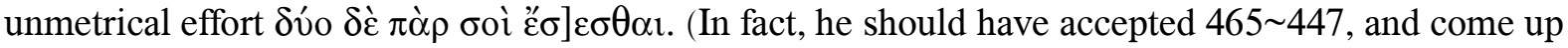
with something else for the start of 466.) He therefore drew a box across his sheet and the original paper, including his earlier supplement, and crossed it like a Union Jack to communicate that 465 and the erroneous reduplication of 448-52 should be omitted. Well might both an editor and a conservator complain.

University of Cambridge, Faculty of Classics

Oliver Thomas

Sidgwick Avenue

Cambridge CB3 9DA, UK

orht3@cam.ac.uk

\section{Bibliography}

Baumeister, A. 1860. Hymni Homerici (Leipzig)

Buecheler, F. 1869. Hymnus Cereris Homericus (Leipzig)

Gelzer, T. 1994. Zum Codex Mosquensis und zur Sammlung der Homerischen Hymnen, Hyperboreus 1, 113-36

Goodwin, A. 1893. Hymni Homerici (Oxford)

Harlfinger, D. 1977. Zu griechischen Kopisten und Schriftstilen des 15. und 16. Jahrhunderts, in: Bompaire, J. and Irigoin, J. (edd.) La paléographie grecque et byzantine (Paris), 327-62

Hignard, L.H.V. 1864. Des hymnes homériques (Paris)

LfgrE: Snell, B. et al. (edd.) 1955-2010. Lexikon des frühgriechischen Epos (Göttingen)

\footnotetext{
7) This sequence could explain why he supplemented and 'emended' 399 on the basis of the later line 446.
} 
Merkelbach, R., van Thiel, H. 1965. Griechisches Leseheft: zur Einführung in Paläographie und Textkritik (Göttingen)

Mitscherlich, C.W. 1787. Homeri Hymnus in Cererem (Leipzig)

Richardson, N. 1974. The Homeric Hymn to Demeter (Oxford)

Ruhnken[ius], D. 1782. Homeri Hymnus in Cererem (Leiden) [superseding the withdrawn 1780 edition]

West, M.L. 1990. Aeschylus: tragoediae cum incerti poetae Prometheo (Stuttgart) 